\title{
Caterpillar saliva interferes with induced Arabidopsis thaliana defence responses via the systemic acquired resistance pathway
}

\author{
Marie-Hélène Weech, Mélanie Chapleau, Li Pan, Christine Ide and Jacqueline C. Bede* \\ Department of Plant Science, McGill University, 21,111 Lakeshore, Ste-Anne-de-Bellevue, Québec, Canada \\ H9X 3V9
}

Received 5 March 2008; Revised 17 March 2008; Accepted 18 March 2008

\begin{abstract}
Arabidopsis thaliana (L.) Heynh. genotypes limited in their ability to mount either octadecanoid-dependent induced resistance $\left(\mathrm{IR}^{-}\right)$or systemic acquired resistance $\left(\mathrm{SAR}^{-}\right)$were used to characterize the roles of these pathways in plant-herbivore interactions. Molecular and biochemical markers of IR were analysed in plants subject to herbivory by caterpillars of the beet armyworm, Spodoptera exigua Hübner, which had either intact or impaired salivary secretions since salivary enzymes, such as glucose oxidase, have been implicated in the ability of caterpillars to circumvent induced plant defences. Transcript expression of genes encoding laccase-like multicopper oxidase [AtLMCO4 (polyphenol oxidase)] and defensin (AtPDF1.2) showed salivary-specific patterns which were disrupted in the SAR ${ }^{-}$mutant plants. The activity of octadecanoid-associated anti-nutritive proteins, such as LMCO and trypsin inhibitor, showed similar patterns. Gene and protein changes parallel plant hormone levels where elevated jasmonic acid was observed in wild-type plants fed upon by caterpillars with impaired salivary secretions compared with plants subject to herbivory by normal caterpillars. This salivary-specific difference in jasmonic acid levels was alleviated in SAR mutants. These results support the model that caterpillar saliva interferes with jasmonatedependent plant defences by activating the SAR pathway.
\end{abstract}

Key words: Caterpillar, cross-talk, gene expression, induced resistance, plant-insect interactions, salivary elicitors, Spodoptera exigua.

\section{Introduction}

Plants defend themselves against the diverse onslaught of pests and pathogens by both general and specific induced defences (Walling, 2000; Kessler and Baldwin, 2002; Bruce and Pickett, 2007; Kessler and Halitschke, 2007). During feeding, wounding of leaf tissue by caterpillars induces the biosynthesis of oxylipin phytohormones, such as jasmonic acid (JA), which results in general octadecanoid-dependent induced resistance (IR) (Farmer et al., 2003; Delessert et al., 2004; Halitschke and Baldwin, 2005). Plants also target their defence responses specifically against the herbivorous insect (Kessler and Halitschke, 2007). In Nicotiana attenuata Torr., genes differentially expressed in response to herbivory by three different caterpillar species showed similar expression profiles (Voelckel and Baldwin, 2004); however, the plant's overall transcriptional response to the two generalist noctuid caterpillar species, Heliothis virescens Fabricius (tobacco budworm) and Spodoptera exigua Hübner (beet armyworm), was more consistent than the response to the sphingid specialist, Manduca sexta L. (tobacco hornworm). Similarly, even though the Arabidopsis relative, Boechera divaricarpa (Nels.) Löve, showed overlapping transcriptional patterns in response to herbivory by caterpillars of the crucifer specialist Plutella xylostella L. (diamondback moth) or the generalist Trichoplusia ni Hübner (cabbage looper), numerous genes were regulated in distinct patterns that indicated interactions between the octadecanoid/ethylene or octadecanoid/salicylic acid (SA) pathways, respectively, resulting in species-specific responses (Vogel et al., 2007). Presumably, the ability of the plant to modify defence responses to target the herbivore lies in

* To whom correspondence should be addressed. E-mail: jacqueline.bede@ mcgill.ca 
the recognition of caterpillar-related elicitors or other signals which are detected by the plant.

After grinding leaf tissue with their mandibles, caterpillars use oral secretions to transport food into their mouthparts. These oral secretions, which are comprised of regurgitant and labial and mandibular saliva, contain a milieu of potential elicitors that are recognized by the plant and shape its defence response. Treatment of wounded corn seedlings or tobacco with volicitin, which is found in the insect regurgitant, induces the synthesis and release of volatiles that lure predators or parasitoids of the herbivorous caterpillar to the plant (Alborn et al., 1997; Turlings et al., 2000; Kessler and Baldwin, 2001, 2002). Labial saliva of some caterpillar species contains oxidoreductases, such as glucose oxidase (GOX), which may enable the insect to circumvent induced plant defences (Musser et al., 2002, 2005).

The basis of GOX action is believed to be through the activation of phytohormone pathways which interact and modify the plant's typical responses (Rojo et al., 2003; Zhu-Salzman et al., 2005; Fujita et al., 2006; Torres et al., 2006; Bodenhausen and Reymond, 2007). In response to wounding or caterpillar herbivory, the rapid biosynthesis of octadecanoids leads to jasmonate-dependent IR (Devoto and Turner, 2003; Howe, 2004; Halitschke and Baldwin, 2005; Wasternack et al., 2006). In systemic tissues, JA and its isoleucine-conjugated form, isoleucine$\mathrm{JA}$, activates the $\mathrm{SCF}^{\mathrm{Co} 1}$ ubiquitin-proteasome-mediated degradation of the jasmonate ZIM domain (JAZ) protein, which negatively regulates the master transcription factor MYC2, leading to the induction of JA-dependent plant defences (Devoto et al., 2002; Xu et al., 2002; Chini et al., 2007; Dombrecht et al., 2007; Thines et al., 2007). Another potential target of the $\mathrm{SCF}^{\mathrm{Co} 1}$ ubiquitin-proteasome is histone deacetylase which adds a layer of epigenetic regulation to JA-responsive gene expression (Devoto et al., 2002). However, production of hydrogen peroxide by caterpillar salivary oxidoreductases is believed to interfere with these responses by acting as an upstream signal to the production of hormones, such as ethylene, or activation of signalling proteins, such as NPR1 (nonexpresser of $\underline{\mathrm{PR}}$ genes 1), which attenuate octadecanoid responses (Winz and Baldwin, 2001; Spoel et al., 2003; Pieterse and van Loon, 2004; Fobert and Després, 2005; Foyer and Noctor, 2005; Lou and Baldwin, 2006).

NPR1 is part of the systemic acquired resistance (SAR) pathway which is activated in plant pathogen defence (Dong, 2004; Pieterse and van Loon, 2004). Upstream molecules in this pathway, SA and reactive oxygen species (ROS), positively affect each other's production in a feedforward mechanism that leads to the oxidative burst and, ultimately, the hypersensitive response (Chen et al., 1993; León et al., 1995; Durrant and Dong, 2004). The disulphide bridges of the cytosolic oligomeric NPR1 protein are reduced as cellular redox changes alter the glutathione redox status and/or biosynthesis (Després et al., 2003; Mou et al., 2003; Ball et al., 2004; Senda and Ogawa, 2004). Monomeric NPR1 enters the nucleus and binds to TGA transcription factors, leading to SAdependent gene expression (Kinkema et al., 2000; Fan and Dong, 2002; Després et al., 2003; Mou et al., 2003; Blanco et al., 2005; Wang et al., 2006). However, NPR1 also interferes with the IR pathway, either by inhibiting octadecanoid biosynthesis or by preventing degradation of JAZ or histone deacetylase proteins, or by activating transcription of AtWRKY transcription factors which repress JA-responsive genes (Devoto et al., 2002; Xu et al., 2002; Spoel et al., 2003; Li et al., 2004; Beckers and Spoel, 2006; Miao and Zentgraf, 2007). Therefore, crosstalk between SAR and IR pathways may be mediated through the production of hydrogen peroxide by caterpillar salivary enzymes, leading to activation of NPR1 and subsequent interference with IR-dependent induced plant defences.

This study used Arabidopsis thaliana (L.) Heynh. plants with mutations in the IR or SAR pathways to elucidate the involvement of caterpillar saliva in mediating the crosstalk between these signalling pathways. Chloroplast lipoxygenase2 (LOX2; EC.1.13.11.12) catalyses the second step in octadecanoid biosynthesis. Therefore, Atlox2 is impaired in its ability to mount IR in response to wounding; however, plants still show constitutive, basal octadecanoid levels (Bell et al., 1995). The $\mathrm{SAR}^{-}$double mutant is unable to produce functional proteins of non-race specific disease resistance1 (NDR1-1) and NPR1-2 (Zhang and Shapiro, 2002). The plasma membrane-associated NDR1-1 protein interacts with the negative regulator RPM1-interacting protein (RIN4) to enable downstream SA/ROS-dependent defence responses to proceed (Shapiro and Zhang, 2001; Day et al., 2006). NPR1-2 functions downstream of NDR1-1, and the activated form of this protein interferes with jasmonate-dependent defence responses (Glazebrook et al., 1996; Beckers and Spoel, 2006; Wang et al., 2006). The Atndrl-1, nprl-2 $\mathrm{SAR}^{-}$ double mutant is unable to accumulate hydrogen peroxide or SA when faced with pathogen challenge (Zhang et al., 2004). Therefore, hydrogen peroxide produced by caterpillar feeding will not enhance SA biosynthesis, and any resultant changes in cellular redox potential should not lead to NPR1-mediated inhibition of the IR pathway in these $\mathrm{SAR}^{-}$plants.

Typical markers of the IR pathway in Arabidopsis, such as AtLOX2, defensin (AtPDF1.2), trypsin inhibitor (AtTI), and laccase-like multicopper oxidase [LMCO (polyphenol oxidase)] (Bell and Mullet, 1993; Creelman and Mullet, 1997; Koiwa et al., 1997; Penninckx et al., 1998; Cipollini et al., 2004), were monitored in these mutant lines to determine if caterpillar saliva is involved in the cross-talk between the IR and SAR pathways. Wound- and JA-inducible LOX2 is part of a feedforward 
cascade that rapidly leads to elevated JA biosynthesis during plant defence signalling (Bell and Mullet, 1993; Sasaki et al., 2001; Wasternack, 2007). The antimicrobial peptide defensin (AtPDF1.2) is another marker of JAdependent gene expression (Penninckx et al., 1998). TI and LMCO are anti-nutritive defences mounted by the plant (Duffey and Stout, 1996; Felton, 2005). As caterpillars feed on the plant, LMCOs oxidize diphenolics present in the leaf tissue to highly reactive ortho-quinones, which covalently modify free amino and sulphydryl groups on dietary proteins preventing their digestion and absorption by the caterpillar (Duffey and Stout, 1996; Wang and Constabel, 2004; Mayer, 2006; Pourcel et al., 2007). Serine proteinase inhibitors, such as TI, lower the nutritive quality of the diet by inhibiting caterpillar proteinases, such as trypsin, impairing protein digestion (Koiwa et al., 1997; Zavala et al., 2004; Wu et al., 2006). In this study, the effect of mechanical damage or caterpillar herbivory was determined on levels of AtLOX2, AtPDF1.2, and AtLCMO4 transcripts, AtTI protein levels, and the enzyme activity of AtLCMO.

Another tool to determine the influence of caterpillar saliva on plant defence responses involves the cauterization of the spinneret. In the beet armyworm, S. exigua, labial saliva is secreted through the caterpillar spinneret during feeding (Musser et al., 2002). Burning this spinneret impairs labial salivary secretions but does not impact herbivory (Musser et al., 2002; Bede et al., 2006). Therefore, Arabidopsis plants (parental wild type, and $\mathrm{IR}^{-}$ or $\mathrm{SAR}^{-}$mutants) were subjected to one of four treatments (control, mechanical damage, and herbivory by caterpillars with intact or impaired salivary secretions), and the resultant effect on IR was monitored at the molecular and biochemical levels.

\section{Materials and methods}

\section{Arabidopsis cultivation}

Arabidopsis seeds [wild type (Col-0; TAIR \#CS3749), IR $^{-}$mutant (T-DNA line, Atlox2 (At3g45140); TAIR \#CS3748), SAR ${ }^{-}$mutant (null mutation in Atndrl-1 and point mutations in Atnprl-2 (At3g50600, At1g642080); TAIR \# CS6355] were obtained from the Arabidopsis Biological Resource Center (TAIR; Ohio State University), sown in Premiere Promix BX (Premier Horticulture Inc.) mixed with slow-release Nutricote (Plant Products; 14-14-14; $5.2 \mathrm{~g} \mathrm{~kg}^{-1}$ Promix), and grown in a phytorium growth cabinet (light intensity $140 \mu \mathrm{E} \mathrm{m}^{-2} \mathrm{~s}^{-1}$ set at a 12:12 h light:dark schedule with temperatures of $23 / 21{ }^{\circ} \mathrm{C}$ ). Plants were bottom-watered as needed, $\sim 3$ times per week. Three 5-week-old plants, one from each genotype and of approximately the same growth stages, were transplanted to larger pots $(16 \mathrm{~cm}$ diameter). At 6 weeks, pots were encased in a plastic chamber and 7-week-old plants, which were between growth stage 6.2 and 6.5 according to Boyes et al. (2001), were used for herbivore experiments.

\section{Insect rearing}

The beet armyworm, S. exigua (Hübner) (Lepidoptera: Noctuidae), colony was reared for multiple generations from eggs purchased from AgriPest Inc. (Zebulon, NC, USA) under defined conditions in a growth cabinet (16:8 h light:dark; $28-40 \%$ relative humidity; $\left.28.5^{\circ} \mathrm{C}\right)$. Caterpillars were maintained on a wheat germ-based artificial diet (Bio-Serv, Frenchtown, NJ, USA). Adult moths mated and the eggs were collected to maintain the colony.

\section{Spinneret cauterization}

A subset of fourth instar S. exigua caterpillars were subject to spinneret cauterization to impair labial salivary secretions (Musser et al., 2002; Bede et al., 2006). Early fourth instar caterpillars were selected, cooled on ice, and their spinneret ablated using a hot probe. Cauterized caterpillars were allowed to recover and feed on BioServ diet $(2-4 \mathrm{~h})$ before testing for salivary GOX activity (Bergmeyer, 1974). Briefly, individual caterpillars were placed in medicine cups containing a filter (Glass microfiber, Whatmann, $24 \mathrm{~mm}$ ) saturated with a glucose/sucrose solution $(50 \mathrm{mg}$ of each sugar $\mathrm{ml}^{-1}$; Sigma). Once caterpillars fed on the glass disc, the presence of salivary GOX was tested by incubating the filter paper with 3,3'-diaminobenzidine ( $1 \mathrm{mg} \mathrm{ml}^{-1}, \mathrm{pH} \mathrm{5.8,} \mathrm{Sigma)} \mathrm{and} \mathrm{the}$ enzyme horseradish peroxidase $(2.5 \mathrm{U}$ in $50 \mathrm{mM}$ sodium phosphate buffer, $\mathrm{pH}$ 7.0, Sigma). The presence of a dark brown precipitate indicates that the caterpillar secreted GOX during feeding and had normal salivary secretions. Indications of feeding on the filter disc but the absence of the precipitate showed that spinneret cauterization was successful. Both subpopulations of caterpillars, those with normal and impaired salivary secretions, were separately allowed to feed on Arabidopsis plants for $1 \mathrm{~d}$ prior to the experiment.

\section{Herbivory experiment}

Arabidopsis plants were subject to one of three treatments: herbivory by caterpillars with intact or impaired salivary secretions or remaining untouched (controls). For the caterpillar treatments, six fourth instar $S$. exigua caterpillars with either intact or impaired salivary secretions were introduced to their respective plants. As mentioned above, plants were enclosed in plastic containers and netting was firmly secured to the tops to prevent caterpillar escape. After $36 \mathrm{~h}$ of treatment, plants were collected and prepared for analysis. For each independent biological replicate, at least two plants of each genotype and treatment were randomly collected for biomass, gene expression, TI and LMCO activity, and hormonal analyses. Arabidopsis which were flowering were discarded. Plants for biomass analysis were cleaned, weighed, and pressed for later measurement of dry weight. Aerial tissues of all other plants were collected, quickly frozen in liquid nitrogen and stored at $-80^{\circ} \mathrm{C}$ until analysis. This experiment was repeated three times independently.

\section{RNA extraction and cDNA synthesis}

For each treatment and replicate, at least one plant of each genotype (27 total) was rapidly ground with a mortar and pestle and total RNA extracted using the RNeasy Mini kit (Qiagen), following the manufacturer's instructions. After DNase treatment [Wipeout, QuantiTect Reverse Transcription kit (Qiagen)], the absence of DNA contamination was confirmed using primers $5^{\prime}$-ATG GGT CGT CAT CAG ATT CAG AGC AGA TAA-3' and 5' -CAT ATA AGA GGT GTG TTA GAG ACA ATA ATA-3' which span an intronic region. A cDNA copy was generated from $1 \mu \mathrm{g}$ of total RNA following the manufacturer's protocol.

\section{Quantitative real time-polymerase chain reaction ( $q R T-P C R$ )}

Gene-specific primers were identified from the literature (Jirage et al., 2001) or designed using AtRTPrimer (Han and Kim, 2006) and expression analysed by qRT-PCR using a Mx3000p thermocycler (Stratagene). Transcript expression was performed in 
duplicate using the Brilliant One-Step quantitative RT-PCR kit (Stratagene), according to the manufacturer's protocol. For each gene, purified PCR amplicons, which were sequenced for verification, were used to prepare a standard curve. A non-template control was also included for every gene. Each reaction contained $1 \times$ SYBR green I, $0.375 \mathrm{nM}$ ROX, $175 \mathrm{nM}$ or $200 \mathrm{nM}$ each of genespecific forward and reverse primers (Table 1), serial dilutions of PCR amplicon or $1.25 \mathrm{ng}$ of cDNA, and mastermix, which contained dNTPs, $\mathrm{MgSO}_{4}$, and Taq polymerase. Thermocycler conditions used were as follows: $95{ }^{\circ} \mathrm{C}$ for $10 \mathrm{~min}$; 40 cycles of annealing temperature for $1 \mathrm{~min}$, then $72{ }^{\circ} \mathrm{C}$ for $30 \mathrm{~s}$, followed by $95{ }^{\circ} \mathrm{C}$ for $1 \mathrm{~min}$; one cycle at annealing temperature for $30 \mathrm{~s}$ and $95{ }^{\circ} \mathrm{C}$ for $30 \mathrm{~s}$. The annealing temperatures are given in Table 1. Dissociation curves were produced to confirm amplicon purity. Two plate replicates were performed.

From the standard curves, gene copy numbers were estimated using Mx3000p MxPro v3.20 software. Actin (AtACT2) expression has been shown to be constitutive when Arabidopsis plants were subject to osmotic stress or treated by methyljasmonate (MeJA) and $\mathrm{SA}$, and, therefore, was used in these experiments as the reference gene (Stotz et al., 2000; Dufresne et al., 2008). AtACT was stably expressed within a genotype and not affected by treatments (wild type, $P=0.53 ; \mathrm{IR}^{-}$mutant, $P=0.99 ; \mathrm{SAR}^{-}$mutant, $P=0.22$ ) (Brunner et al., 2004). Normalized gene expression of AtPDF1.2, AtLOX2, and AtLMCO4 was calculated. Within a genotype, transcript expression differences were statistically determined by one-way analysis of variance (ANOVA) using SPSS version 15 (SPSS Inc., Chicago, IL, USA).

\section{Protein extraction}

Arabidopsis plants were ground in liquid nitrogen using a mortar and pestle. To $50 \mathrm{mg}$ of plant material, ice-cold extraction buffer ( $0.1 \mathrm{M}$ sodium phosphate buffer, $\mathrm{pH} 7.0$ containing $0.1 \%$ Triton $\mathrm{X}$ 100 and $7 \%$ PVP) was added, vortexed, and centrifuged (5 min at $17310 \mathrm{~g}$ ), and the supernatant was transferred to a clean $1.5 \mathrm{ml}$ microcentrifuge tube and placed on ice (Wang and Constabel, 2004). Detergent $(0.1 \%$ Triton $X-100)$ in the extraction buffer is necessary for LMCO activation (Yoruk and Marshall, 2003). For the assay of LMCO activity, broad-spectrum proteinase inhibitor solution (Sigma; final concentration $1 \times$ ) was added to the extraction buffer (Yoruk and Marshall, 2003). Samples were used immediately to assay TI or LMCO activity.

\section{Trypsin inhibitor assay}

Analysis of trypsin levels as described by Lara et al. (2000) was modified for a 96-well plate format (Corning, flat-bottomed wells). Briefly, bovine trypsin $(0.5 \mu \mathrm{g}$, treated to reduce chymotrypsin contamination, Sigma) was incubated with either soybean TI (Type $1 \mathrm{~S}$, Sigma; concentration range $0.05 \mathrm{ng}$ to $50 \mu \mathrm{g}$ ) or protein extract at $37{ }^{\circ} \mathrm{C}$ with gentle rocking. After $30 \mathrm{~min}$, the trypsin substrate $\mathrm{N}$ -
benzoyl-DL-arginyl- $\beta$-naphthylamine (BANA, Sigma, $3.1 \mathrm{mM}$ final concentration) was added and allowed to incubate for an additional hour with gentle shaking. To stop the reaction, $2 \% \mathrm{HCl}$ was added. The reagent $p$-dimethyl-amino-cinnamaldehyde (Sigma, final concentration $0.24 \%$ in ethanol) reacts with $\beta$-naphthalene which is released from BANA through trypsin-catalysed hydrolysis. The product was visualized at $540 \mathrm{~nm}$ in a microplate reader (BioTek Synergy HT microplate reader). Controls of TI in the absence of trypsin (blank) as well as trypsin in the absence of TI were included. The standard curve, blanks, and controls were performed in duplicate. All samples were analysed in triplicate. After subtraction of the blank, TI levels in plant samples were calculated from the log of the standard curve using Graphpad 4.0 (Prism).

The $\mathrm{pH}$ of the caterpillar gut is extremely alkaline (Schultz and Lechowicz, 1986; Dow, 1992). Protein structure and stability studies have also indicated that both trypsin and TIs are extremely stable over $\mathrm{pH}$ and temperature ranges (Simon et al., 2001; Garcia et al., 2004). In this study, TI standard curves were initially compared using $1 \mathrm{M}$ borate buffer, $\mathrm{pH} 9.3$ and sodium phosphate buffer, $\mathrm{pH}$ 7.0, and a difference was not observed. Therefore, analysis of plant material was conducted in the sodium phosphatebased extraction buffer to allow comparisons with the literature.

\section{Laccase-like multicopper oxidase enzyme activity}

AtLMCO (EC 1.10.3.2; polyphenol oxidase) (McCraig et al., 2005; Cai et al., 2006) activity was assayed according to Espín et al. (1997) adapted to a 96-well format. To triplicate sample extracts or tyrosinase from mushroom (Sigma, $50 \mathrm{U}$ ), $\mathrm{N}, \mathrm{N}$-dimethylformamide (Sigma, final concentration $0.1 \%$ ) and 3-methyl-2-benzothiazolinone hydrazone hydrochloride monohydrate (Sigma, final concentration $0.2 \mathrm{mM}$ prepared in methanol) were added. These chemicals act to stabilize the reactive quinones generated through the LMCO reaction to prevent them from inactivating the enzyme activity. After the addition of dopamine hydrochloride (Sigma, final concentration $35 \mathrm{mM}$ ), enzyme activity was monitored at $30 \mathrm{~s}$ intervals for $5 \mathrm{~min}$ at $476 \mathrm{~nm}$ at $35{ }^{\circ} \mathrm{C}$ using a multiplate reader. Enzyme-free and boiled controls were included.

Many plant laccases are latent, requiring activation by protease, such as trypsin, in the caterpillar gut or, in the laboratory, using SDS in the extraction buffer (Yoruk and Marshall, 2003). Activation by SDS requires a neutral $\mathrm{pH}$; therefore, these LMCO activity assays were conducted at pH 7.0 (Sellés-Marchant et al., 2007). Trypsin-mediated activation has a broader $\mathrm{pH}$ range and, presumably, occurs in the extremely alkaline caterpillar gut (Schultz and Lechowicz, 1986; Dow, 1992; Wang and Constabel, 2004).

\section{Protein assay}

Levels of soluble, extracted protein were measured by Bradford assay (Pierce) at $595 \mathrm{~nm}$ in a 96-well format (Bradford, 1976). A standard curve was generated using duplicate samples of bovine

Table 1. Primers used for $q R T-P C R$ expression analysis

\begin{tabular}{|c|c|c|c|c|c|}
\hline Gene & Forward primer $\left(5^{\prime}-3^{\prime}\right)$ & Reverse primer $\left(5^{\prime}-3^{\prime}\right)$ & $\begin{array}{l}\text { Annealing } \\
\text { temperature } \\
\left({ }^{\circ} \mathrm{C}\right)\end{array}$ & $\begin{array}{l}\text { Amplicon } \\
\text { size (bp) }\end{array}$ & Reference \\
\hline AtPDF1.2 (At2g2620) & CGGCAATGGTGGAAGCA & CATGCATTACTGTTTCCGCAA & 59 & 79 & \multirow{4}{*}{$\begin{array}{l}\text { Jirage } \text { et al. } \\
(2001) \\
\text { Designed using } \\
\text { AtRTPrimer } \\
\text { Designed using } \\
\text { AtRTPrimer } \\
\text { Dufresne } \text { et al. } \\
\text { (2008) }\end{array}$} \\
\hline AtLOX2 (At3g45140) & GTCCTACTTGCCTTCCCAAAC & ATTGTCAGGGTCACCAACATC & 57 & 160 & \\
\hline AtLMCO4 (At2g38080) & AGGTCCCACAATCTACGCACGA & CCATCCCGTTCTCACTTGTCTCACA & 58 & 115 & \\
\hline AtACT2 (At3g18780) & ACCAGCTCTTCCATCGAGAA & GAACCACCGATCCAGACACT & & 338 & \\
\hline
\end{tabular}


serum albumin (dilution range: $0.35-6.9 \mu \mathrm{g}$ ). Leaf extracts were analysed in triplicate. Blank controls consisted of Bradford reagent with extraction buffer.

\section{Estimation of leaf loss due to caterpillar herbivory}

Dry weights of the vegetative tissue from two replicates of each genotype and treatment for each experimental replication were measured to determine the estimated leaf tissue removed by caterpillar herbivory $(n=6)$.

\section{Hormone analysis}

Foliar levels of JA and SA were analysed by high-performance liquid chromatography electrospray tandem mass spectroscopy (HPLC/ESMS/MS) at the Plant Biotechnology Institute of the National Research Council of Canada. Three biological replications of wildtype or $\mathrm{SAR}^{-}$plants subject to herbivory by caterpillars with either intact or impaired salivary secretions were frozen in liquid nitrogen. Plant material was ground to a fine powder in liquid nitrogen. Extraction of $\sim 300 \mathrm{mg}$ samples was performed by adding $3 \mathrm{ml}$ of methanol:water:glacial acetic acid (90:9:1, by vol.) extraction solution and the internal standard [100 ng of 3,4,5,6- $\mathrm{d}_{4}-2$ hydroxybenzoic acid and $50 \mathrm{ng}$ of 2,2- $\mathrm{d}_{2}$-jasmonic acid dissolved in $15 \%$ acetonitrile in water $+0.1 \%$ formic acid (Galka et al., 2005)]. Following sonication $(5 \mathrm{~min})$ and incubation on an orbital shaker $\left(4{ }^{\circ} \mathrm{C}, 5 \mathrm{~min}\right)$, samples were centrifuged $(17310 \mathrm{~g}, 10 \mathrm{~min})$ to pellet the debris. The supernatant was transferred to a clean tube and the pellets were re-suspended in $2 \mathrm{ml}$ of the extraction solution. Sonication, extraction on the orbital shaker, and centrifugation were repeated. The supernatant was combined with the initial extracted volume and the pellet was re-suspended in $1 \mathrm{ml}$ of methanol. The extraction step was repeated a third time. After the supernatants were combined, methanol was evaporated under a constant stream of nitrogen. A $2 \mathrm{ml}$ aliquot of $0.1 \mathrm{M} \mathrm{NaOH}$ was added to the residual water phase and neutral components were removed by extraction with $3 \mathrm{ml}$ of dichloromethane. After phase separation, the water layer was transferred to a clean tube. The dichloromethane layer was re-extracted with $0.1 \mathrm{M} \mathrm{NaOH}(2 \mathrm{ml})$. Both aqueous layers were combined and acidified with $5 \%$ aqueous $\mathrm{HCl}$ on ice followed by the partitioning with $1 \mathrm{ml}$ of ethyl acetate:cyclohexane $(1: 1, \mathrm{v} / \mathrm{v})$ solvent mixture. The organic phase was collected and the water phase was extracted a second time with $0.5 \mathrm{ml}$ of ethyl acetate:cyclohexane mixture. The organic fractions were pooled and the solvent was evaporated under a constant stream of nitrogen. Prior to mass spectrometric analysis, the samples were reconstituted in $100 \mu \mathrm{l}$ of $40 \%$ HPLC-grade methanol in $1 \%$ aqueous formic acid, which contained $100 \mathrm{ng}$ of $1,2,3,4,5,6-{ }^{13} \mathrm{C}_{6}$-2-hydroxybenzoic acid and $50 \mathrm{ng}$ of $12,12,12-\mathrm{d}_{3}$-jasmonic acid to monitor instrument performance.

SA and JA analysis was carried out by HPLC/ES-MS/MS utilizing an HP1100 series binary solvent pump and autosampler (Hewlett-Packard) coupled to a Quattro LC ${ }^{\text {TM }}$ quadrupole tandem mass spectrometer via a Z-spray ${ }^{\mathrm{TM}}$ interface (Micromass, Manchester, UK). The analytical HPLC column was a Zorbax Rapid Resolution $2.1 \times 50 \mathrm{~mm} 1.8 \mu \mathrm{m}$ column (Agilent Technologies). Mobile phase A comprised 1\% formic acid in HPLC-grade water; mobile phase B comprised HPLC-grade methanol. Sample volumes of $5 \mu \mathrm{l}$ were injected onto the column at a flow rate of $0.20 \mathrm{ml}$ $\min ^{-1}$ under initial conditions of $40 \% \mathrm{~B}$, which was maintained for $3 \mathrm{~min}$, then increased to $90 \% \mathrm{~B}$ at $3.1 \mathrm{~min}$, and held until $10 \mathrm{~min}$. B was decreased to $40 \%$ by $11 \mathrm{~min}$ and held until $20 \mathrm{~min}$ for column equilibration before the next injection. The analytes were ionized by negative-ion electrospray using the following conditions: capillary potential $2.5 \mathrm{kV}$; cone voltage $30 \mathrm{~V}$; desolvation gas flow $600 \mathrm{l} \mathrm{h}^{-1}$; source and desolvation gas temperatures, $120{ }^{\circ} \mathrm{C}$ and $350{ }^{\circ} \mathrm{C}$, respectively. Analytical procedures analogous to those reported in Ross et al. (2004) were employed to determine the quantities of SA and JA in the plant extracts. Briefly, analysis utilizes the Multiple Reaction Monitoring (MRM) function of the MassLynx v3.5 (Micromass) control software wherein the instrument monitors the loss of a neutral $\mathrm{CO}_{2}$ moiety from the deprotonated parent ion during collision-induced dissociation (CID). The transitions monitored for the standards as well as undeuterated analytes are $m / z$ (mass-to-charge ratio): $137>93$ for SA, $141>97$ for $\mathrm{d}_{4}$-SA; $143>99$ for ${ }^{13} \mathrm{C}_{6}$-SA; $209>59$ for JA; $211>61$ for $\mathrm{d}_{2}-\mathrm{JA}$; and $212>59$ for $\mathrm{d}_{3}-\mathrm{JA}$. The resulting chromatographic traces are quantified off-line by the QuanLynx v4.0 software (Micromass) wherein each trace is integrated and the resulting ratio of signals (undeuterated/internal standard) is compared with a previously constructed calibration curve to yield the amount of analyte present (ng per sample).

\section{Statistical analysis}

The experiment was repeated three times independently. Transcript and hormone levels were analysed in one plant from each experimental replicate $(n=3)$. TI levels, LMCO activity and soluble protein levels, as well as the amount of caterpillar damage were analysed in two plants from each experimental replicate $(n=4-6)$. Outliers were detected using the Grubbs' test (Prism GraphPad). Within each genotype, data were analysed statistically by ANOVA using SPSS version 14 (SPSS Inc.). Statistical differences were determined using a Tukey HSD post hoc test. Significant differences in hormone levels were detected using a two-tailed Student's $t$-test.

\section{Results and discussion}

\section{Caterpillar damage}

Arabidopsis damage resulting from caterpillar herbivory was roughly estimated by measuring aerial tissue dry weight. Between $23 \%$ and $31 \%$ of plant tissue was removed by caterpillar herbivory, irrespective of Arabidopsis genotype or cauterization treatment.

\section{Arabidopsis hormone levels}

In response to caterpillar feeding, plants mount a rapid induction of biosynthesis of jasmonate and related octadecanoid compounds, such as 12-oxo-phytodienoic acid (OPDA) and dinor OPDA, which together lead to the induction of plant defence responses (Kahl et al., 2000; Reymond et al., 2004). This may manifest itself as a rapid, transient burst which, depending on the plant species, may be followed by a steady increase over a period of at least $24 \mathrm{~h}$ (Reymond et al., 2004; Zavala et al., 2004; Rayapuram and Baldwin, 2007). Free JA levels were measured in wild-type and $\mathrm{SAR}^{-}$mutant plants which had been subject to herbivory by caterpillars with intact or impaired salivary secretions to determine if salivary elicitors interfere with changes in phytohormone levels. Wild-type plants eaten by cauterized caterpillars compared with plants infested by caterpillars with normal salivary secretions had similar SA levels $\left[<5 \mu \mathrm{g} \mathrm{g}^{-1}\right.$ frozen weight, $\left.t_{(4)}=-1.27 ; P=0.27\right]$ but $>4$ times more JA $\left[t_{(4)}=\right.$ -7.27; $P=0.002]$ (Fig. 1). Induced levels in this range have been previously observed in Arabidopsis plants 
subject to herbivory by first instar caterpillars of the crucifer specialist $P$. rapae (Reymond et al., 2004). The salivarydependent difference in JA levels observed in wild-type plants was not seen in the $\mathrm{SAR}^{-}$double mutants $\left[t_{(4)}=\right.$ $-1.23 ; P=0.29$ ].

$\mathrm{SAR}^{-}$mutant plants have basal, constitutive levels of SA which do not increase in response to pathogen attack (Zhang et al., 2004). In response to caterpillar herbivory, SA levels in the $\mathrm{SAR}^{-}$plants were consistently low $\left(<5 \mu \mathrm{g} \mathrm{g}^{-1}\right.$ frozen weight) and salivary-specific differences were not observed in either the wild-type or $\mathrm{SAR}^{-}$ mutant plants [data not shown; $t_{(4)}=-1.27$; wild type, $P=0.27 ; \mathrm{SAR}^{-}$mutant, $\left.t_{(4)}=1.40 ; P=0.22\right]$. These data suggest that a factor(s) in caterpillar saliva acts directly or indirectly as a negative regulator of JA biosynthesis by an SA-independent mechanism.

\section{Induced plant defences}

LOX2 catalyses the second step in octadecanoid biosynthesis; the conversion of $\alpha$-linolenic acid to $13(S)$ hydroperoxy-9(Z),11(E),15(Z)-octadecatrienoic acid (Vick and Zimmerman, 1976; Mueller, 1997). In Arabidopsis and other plant species, constitutive, basal AtLOX2 transcript levels are rapidly induced in response to injury (Bell and Mullet, 1993; Heintz et al., 1997; Zheng et al., 2007). Also, octadecanoids may further stimulate AtLOX2 expression, leading to a transient jasmonate burst (Sasaki et al., 2001; Ziegler et al., 2001). In wild-type and SAR ${ }^{-}$ Arabidopsis plants, caterpillar herbivory resulted in a $>4-$ fold increase in AtLOX2 expression (Fig. 2A); however, due to the large variation in gene expression, significant differences in response to treatment are not observed [wild type, $F_{(2,6)}=2.17 ; P=0.20 ;$ SAR mutant, $F_{(2,6)}=1.27$; $P=0.35]$.

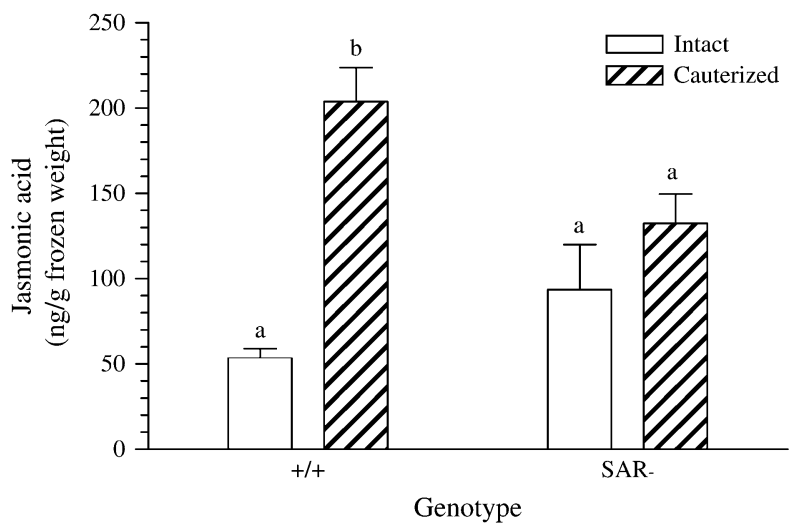

Fig. 1. Arabidopsis jasmonic acid levels in response to caterpillar herbivory. Levels of free jasmonic acid (JA) were measured in 7-weekold Arabidopsis plants [Col-0 parental (+/+) or Atndr1-1, nprl-2 double mutant $\left.\left(\mathrm{SAR}^{-}\right)\right]$that were subject to caterpillar herbivory by caterpillars with normal (intact) or impaired (cauterized) salivary secretions for $36 \mathrm{~h}$. Bars represent the means of three independent replicates \pm SE. Within each genotype, the lower case letters indicate significant differences $(P \leqslant 0.05)(n=3)$.
Transcript AtLOX2 levels do not show caterpillar salivary-specific regulation, yet JA levels reflect salivary status. In the wild-type, $\mathrm{SAR}^{-}$mutant, and, to some extent, even in the $\mathrm{IR}^{-}$mutant plants, AtLOX2 expression levels are elevated in response to caterpillar herbivory regardless of the salivary status of the caterpillars (Fig. $2 \mathrm{~A})$. This is reminiscent of a model proposed by Huang et al. (2004) where nitric oxide is an upstream signal leading to the activation of $A t L O X 2$ and the repression of $A t O P D A$ via SA. Perhaps, wound-related nitric oxide levels induce AtLOX2 gene expression, yet the negative regulator associated with caterpillar saliva inhibits JA biosynthesis downstream of this point.

AtPDF1.2 encodes the ethylene- and JA-dependent defence protein defensin (Penninckx et al., 1998). Wildtype plants damaged by herbivory by cauterized caterpillars show a $>5$-fold increase in AtPDF1.2 expression
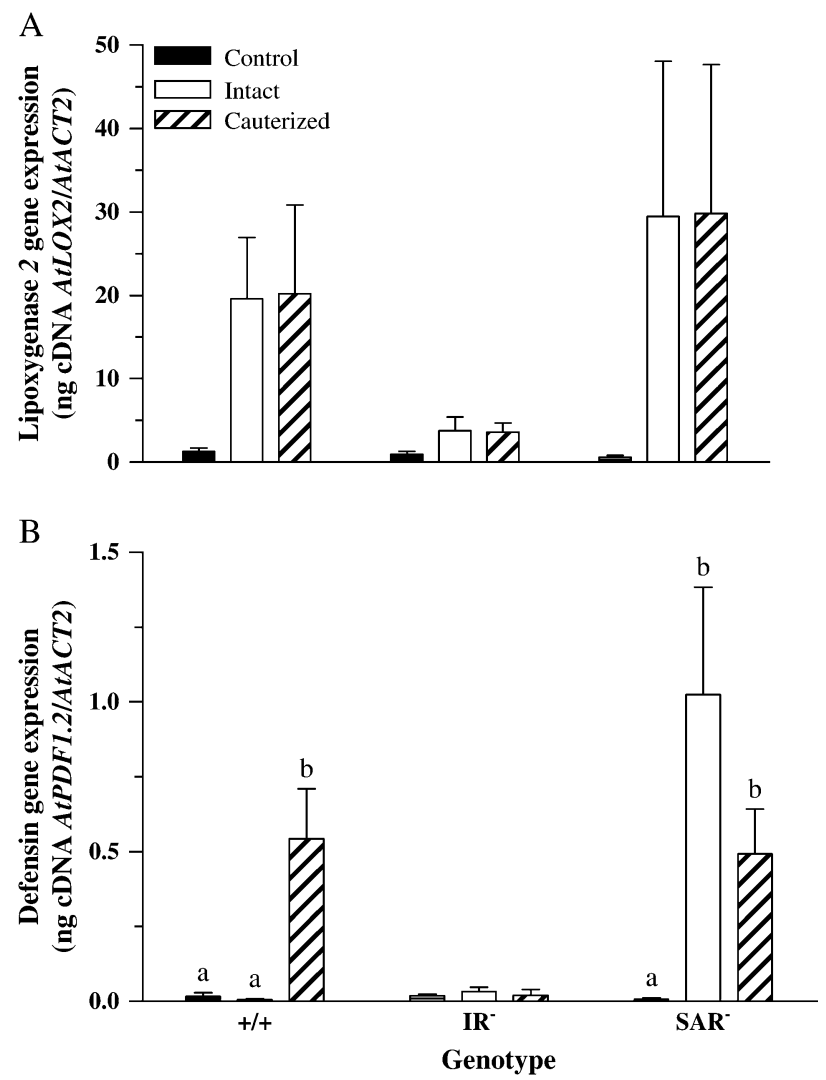

Fig. 2. Transcript expression of genes encoding lipoxygenase 2 (AtLOX2) and defensin (AtPDF1.2) in response to caterpillar herbivory. Seven-week-old Arabidopsis plants [Col-0 parental (+/+), Atlox2 mutant (IR ${ }^{-}$, and Atndrl-1, nprl-2 double mutant $\left.\left(\mathrm{SAR}^{-}\right)\right]$were subject to caterpillar herbivory by caterpillars with normal (intact) or impaired (cauterized) salivary secretions for $36 \mathrm{~h}$. cDNA was prepared from total RNA extracted from vegetative tissue, and transcript expression was analysed by qRT-PCR using gene-specific primers. AtLOX2 (A) and AtPDF1.2 (B) are markers of JA-dependent gene expression (Bell and Mullet, 1993; Penninckx et al., 1998). Bars represent the means of three independent replicates normalized with the reference gene actin $($ AtACT2) \pm SE. Within each genotype, lower case letters indicate significant differences $(P \leqslant 0.05)(n=3)$. 
levels compared with control plants $\left[F_{(2,6)}=10.29\right.$; $P=0.012]$ (Fig. 2B). In comparison, herbivory by caterpillars with normal labial salivary secretions prevents the induction of AtPDF1.2 transcription. Reymond et al. (2004) observed a similar pattern where AtPDF1.2 gene expression was induced in response to wounding but not herbivory by $S$. littoralis or $P$. rapae caterpillars. In other studies, $P$. rapae caterpillar feeding resulted in strong, localized AtPDF1.2 transcript expression, but whole leaf levels were too low to be detected (De Vos et al., 2006). A caterpillar-specific increase in AtPDF1.2 expression was observed in $\mathrm{SAR}^{-}$double mutants $\left[F_{(2,6)}=5.13\right.$; $P=0.05]$; however, in comparison with wild-type plants, a saliva-specific difference was not seen. Herbivoryinduced AtPDF1.2 expression was not observed in the $\mathrm{IR}^{-}$mutants $\left[F_{(2,6)}=1.54 ; P=0.29\right]$.

Caterpillars feeding on plant leaves often face protein limitations, in terms of quality and quantity (Mattson, 1980; Felton, 1996; Bede et al., 2007). Also, plants have jasmonate-dependent anti-nutritive defences that interfere with caterpillar protein digestion, such as proteinase inhibitors, LMCO, or enzymes which deaminate essential amino acids (Duffey and Stout, 1996; Koiwa et al., 1997; Zavala et al., 2004; Chen et al., 2005; Felton, 2005). LMCOs oxidize foliar polyphenolics to reactive quinones which bind to proteins undergoing digestion in the caterpillar gut, preventing their absorption (Duffey and Stout, 1996; Pourcel et al., 2007). Though a recent study has shown that, contrary to expectations, lymantriid caterpillars of Lymantria dispar L. (gypsy moth) and Orgyia leucostigma Smith (white-marked tussock moth) did not suffer negative consequences by feeding on transgenic poplar trees with elevated LMCO levels (Barbehenn et al., 2007), further studies are needed to ascertain the generality of these observations. AtLMCO gene expression and enzyme activity increased in wild-type plants subject to herbivory by caterpillars with impaired labial salivary secretions [LMCO transcript expression, $F_{(2,7)}=8.38$, $P=0.014$; LMCO activity, $F_{(2,7)}=8.18, P=0.015$ ] (Fig. $3 \mathrm{~A}, \mathrm{~B})$. This caterpillar-specific difference is not observed in the $\mathrm{SAR}^{-}$double mutant [LMCO transcript expression: $F_{(2,6)}=811.64, P=0.009$; LMCO activity, $F_{(3,9)}=12.18$, $P=0.003]$. Since this is a JA-dependent defence, treatment does not affect transcript levels or enzyme activity in the $\mathrm{IR}^{-}$mutant [LMCO transcript expression, $F_{(2,6)}=1.40$, $P=0.30 ;$ LMCO activity, $\left.F_{(2,13)}=0.38, P=0.695\right]$.

Upon ingestion, many plant LMCOs are latent until activated by trypsin (Yoruk and Marshall, 2003). Therefore, it is interesting that another common jasmonatedependent plant defence to interfere with caterpillar nutritional intake are serine proteinase inhibitors, such as TIs, which hinder protein digestion by binding to the caterpillar digestive enzyme trypsin in the gut, thereby reducing protein digestion (Koiwa et al., 1997; Cipollini et al., 2004; Clauss and Mitchell-Olds, 2004; Zavala et al.,
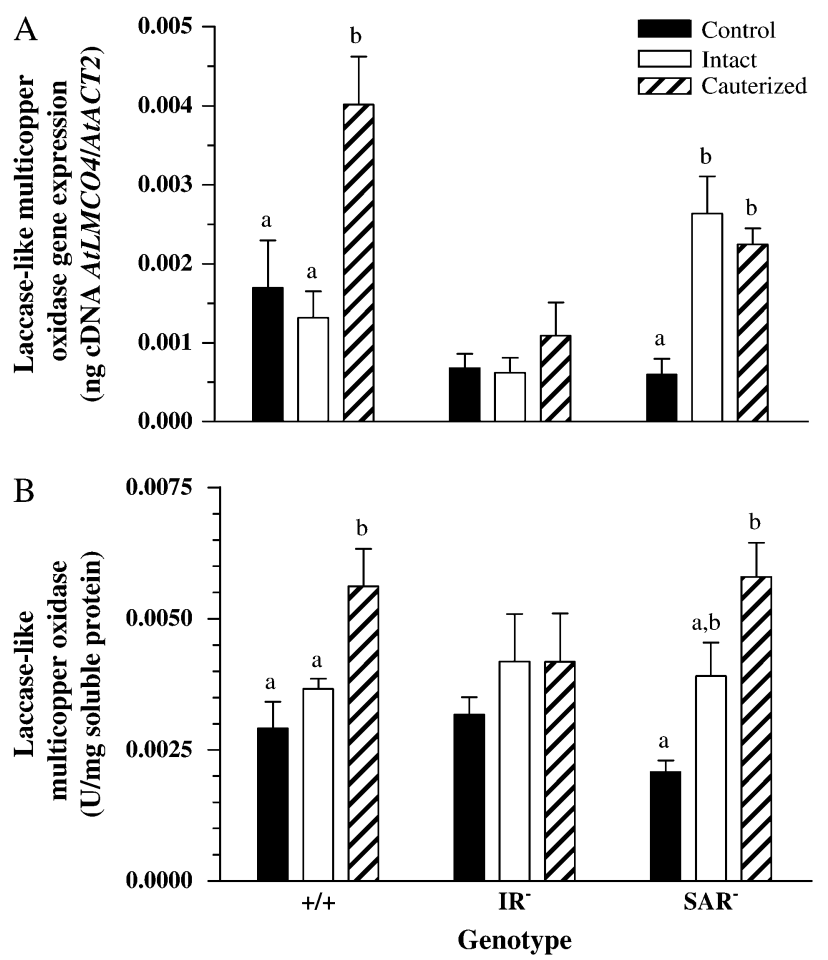

Fig. 3. Transcript expression and enzyme activity of laccase-like multicopper oxidase (LMCO) in response to caterpillar herbivory. Seven-week-old Arabidopsis plants [Col-0 parental (+/+), Atlox 2 mutant $\left(\mathrm{IR}^{-}\right)$, and Atndrl-1, nprl-2 double mutant $\left.\left(\mathrm{SAR}^{-}\right)\right]$were subject to caterpillar herbivory by caterpillars with normal (intact) or impaired (cauterized) salivary secretions for $36 \mathrm{~h}$. (A) AtLMCO4 gene expression. cDNA was prepared from total RNA extracted from vegetative tissue, and transcript expression was analysed by qRT-PCR using AtLMCO4-specific primers. Bars represent the means of three independent replicates normalized with the reference gene actin (AtACT2) \pm SE. Within each genotype, lower case letters indicate significant differences $(P \leqslant 0.05)(n=3)$. (B) LMCO activity. Bars represent the average LMCO activity per mg of soluble protein of 4-6 plants \pm SE. Within each genotype, lower case letters indicate significant differences $(P \leqslant 0.05)(n=4-6)$.

2004). In Arabidopsis, five members of this multigene family were induced in response to herbivory by third instar P. xylostella caterpillars (Clauss and Mitchell-Olds, 2004). Caterpillar salivary-specific difference in TI levels observed in wild-type plants are not seen in the $\mathrm{SAR}^{-}$ double mutant [wild type, $F_{(2,8)}=7.33, P=0.016$; SAR, $\left.F_{(3,6)}=6.90, P=0.028\right]$ (Fig. 4). As this defence is strongly correlated with JA levels, treatment differences observed in the wild type and $\mathrm{SAR}^{-}$mutant plants are not seen in the $\mathrm{IR}^{-}$mutant $\left[F_{(2,13)}=0.71, P=0.51\right]$.

\section{Caterpillar saliva interferes with JA-dependent plant defences via the SAR pathway}

Using well-established Arabidopsis mutants subject to herbivory by insects with intact and impaired salivary secretions, this study presents evidence that caterpillar labial saliva interferes with octadecanoid-associated induced plant defences. JA hormone levels, AtLMCO4 and AtPDF 1.2 transcript levels, and TI and LMCO activity 


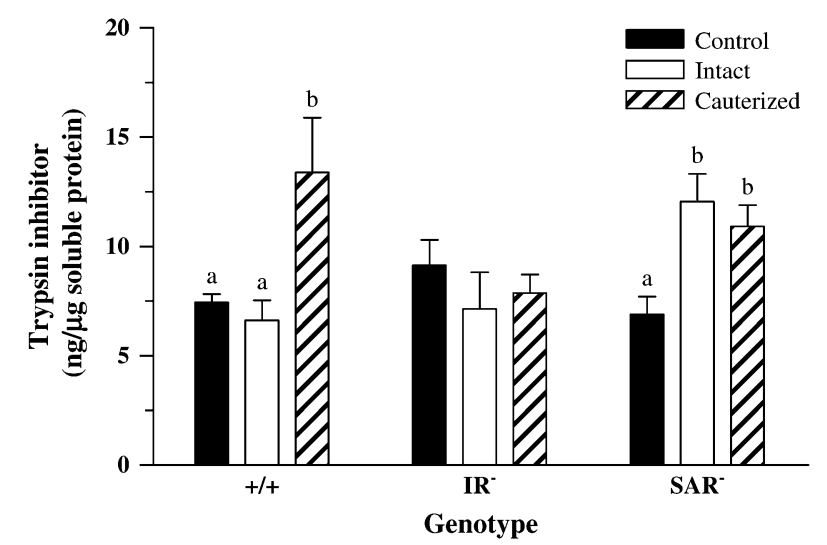

Fig. 4. Trypsin inhibitor levels in response to caterpillar herbivory. Levels of the anti-nutritive protein, trypsin inhibitor, were determined in 7-week-old Arabidopsis plants [Col-0 parental (+/+), Atlox2 mutant $\left(\mathrm{IR}^{-}\right)$, and Atndrl-1, nprl-2 double mutant ( $\left.\left.\mathrm{SAR}^{-}\right)\right]$subject to caterpillar herbivory by caterpillars with normal (intact) or impaired (cauterized) salivary secretions for $36 \mathrm{~h}$. Bars represent means of 3-6 plants \pm SE. Within each genotype, lower case letters indicate significant differences $(P \leqslant 0.05)(n=4-6)$.

show salivary-specific regulation (Figs 1, 2B, 3, 4). Wildtype plants infested by caterpillars with intact salivary secretions did not mount the expected defence responses which are observed when caterpillar salivary secretions are inhibited by cauterization. This salivary-specific difference is alleviated when the $\mathrm{SAR}^{-}$pathway is not present.

The Arabidopsis $\mathrm{SAR}^{-}$mutant plants have a null mutation in the gene encoding the protein NDR1-1 and point mutations in the genes encoding NPR1 and 2 (Zhang and Shapiro, 2002). This double mutation blocks both ROS synthesis and NPR1 function (Zhang et al., 2004). Also, SA does not accumulate in these plants when they are subject to pathogen attack, which was also observed in this study (data not shown).

NPR1 is constitutively present in its cytosolic oligomeric form (Mou et al., 2003). A change in cellular redox potential which, for example, may be associated with increased ROS during plant-pathogen interactions or caterpillar salivary oxidoreductases, reduces NPR1 intermolecular disulphide bonds via activation of glutathione biosynthesis and/or altering glutathione redox status, releasing the monomeric protein (Mou et al., 2003; Ball et al., 2004; Senda and Ogawa, 2004). Activated NPR1 may enter the nucleus and associate with TGA- or WRKY-type transcription factors, leading to SA-dependent gene expression (Després et al., 2003; Mou et al., 2003; Wang et al., 2006). NPR1 is also believed to interfere with JA-dependent gene expression; however, the mechanism by which this occurs is unclear and it may occur by inhibiting octadecanoid biosynthesis or by preventing the JA-dependent, ubiquitin-proteasomemediated degradation of the JAZ protein or histone deacetylase, or by activating WRKY transcription factors
(Devoto et al., 2002; Xu et al., 2002; Beckers and Spoel, 2006; Miao and Zentgraf, 2007; Thines et al., 2007). Recent evidence also supports the involvement of a glutaredoxin protein downstream of NPR1 which upon interaction with TGA2,5,6 transcription factors binds to the promoter region and represses transcription of JA-dependent genes, such as AtPDF1.2 (Ndamukong et al., 2007).

In this study, the salivary-related difference in the induction of JA-related defences is not observed in the $\mathrm{SAR}^{-}$mutants. The small sample size, between three and six depending on the assay, could lead to the observation of false negatives; however, the consistency in response supports the conclusion that a negative JA-regulatory factor present in the caterpillar saliva mediates the activation of NPR1, perhaps through a change in cellular redox potential, leading to the attenuation of octadecanoid-associated defence responses. In wild tobacco, $N$. attenuata, NaNPRI-silenced plants have blocked plant defences and were more susceptible to caterpillar herbivory (Rayapuram and Baldwin, 2007). In the Nicotiana system, reduced NPR1 levels are believed to affect SA biosynthesis positively, resulting in antagonism of JAdependent defences. In the present study, SA levels did not change in response to caterpillar herbivory, possibly demonstrating species-specific differences in the regulation of plant defence pathways.

\section{Conclusion}

Caterpillar elicitors, present in the regurgitant or saliva, modify plant defence responses by affecting interactions between signalling pathways. In response to mechanical injury, plants mount defence and healing responses which are primarily mediated by octadecanoid-related compounds, such as JA (Léon et al., 2001; Howe, 2004). However, other phytohormones, such as ethylene, abscissic acid, nitric oxide, and auxin, and signalling proteins, such as NPR1, can attenuate or accentuate these plant responses by interacting at signalling nodes where it is clear that microlocalization and equilibrium ratios play a critical role in mediating the final cellular response (Orozco-Cárdenas and Ryan, 2002; Gupta and Luan, 2003; Anderson et al., 2004; Huang et al., 2004; Li et al., 2004; Lorenzo et al., 2004; Bostock, 2005; Devoto and Turner, 2005; Lorenzo and Solano, 2005; Wang et al., 2006; Adie et al., 2007; Bodenhausen and Reymond, 2007; Dombrecht et al., 2007; Miao and Zentgraf, 2007; Spoel et al., 2007; von Dahl and Baldwin, 2007). One adaptive strategy of caterpillars to circumvent induced plant defences may be to activate these other signalling pathways which interfere with the plant's normal octadecanoid responses (Musser et al., 2002, 2005). This study raises the possibility that labial salivary enzymes secreted onto leaves as caterpillars are feeding interfere with octadecanoid-responsive plant defences by activating the 
SAR pathway (Devoto et al., 2002; Xu et al., 2002; Després et al., 2003; Mou et al., 2003; Spoel et al., 2003; Li et al., 2004; Pieterse and van Loon, 2004; Fobert and Després, 2005; Foyer and Noctor, 2005; Beckers and Spoel, 2006; Miao and Zentgraf, 2007).

\section{Acknowledgements}

We thank Bejay Mills and Dr Olusegun Lawal for caterpillar maintenance, Rachida Bouchnita for assistance with enzyme assays in preliminary studies, and Dr Marc Fortin for use of the Synergy HT multiplate reader. Hormone analysis was performed by Dr Sue Abrams, Dr Irina Zaharia, and the Plant Hormone Profiling Team at the Plant Biotechnology Institute of the National Research Council of Canada (http://pbi-ibp.nrc-cnrc.gc.ca/en/research/planthormoneprofiling.htm). We are grateful to Shireef Darwish, Dr Gopal Subramaniam, and two anonymous reviewers for discussions and suggestions on an earlier version of this paper. The research was made possible by operating grants from the National Sciences and Engineering Research Council, Canadian Foundation for Innovation Infrastructure Operating Funds and the Fonds Québécois de la Recherche sur la Nature et les Technologies to JCB.

\section{References}

Adie B, Chico JM, Rubio-Somoza I, Solano R. 2007. Modulation of plant defenses by ethylene. Journal of Plant Growth Regulation 26, 160-177.

Alborn HT, Turlings TCJ, Jones TH, Stenhagen G, Loughrin JH, Tumlinson III J. 1997. An elicitor of plant volatiles from beet armyworm oral secretions. Science 276, 945949.

Anderson JP, Badruzsaufari E, Schenk PM, Manners JM, Desmond OJ, Ehlert C, Maclean DJ, Ebert PR, Kazan K. 2004. Antagonistic interaction between abscisic acid and jasmonate-ethylene signaling pathways modulate defense gene expression and disease resistance in Arabidopsis. The Plant Cell 16, 3460-3479.

Ball L, Accotto G-P, Bechtold U, et al. 2004. Evidence for a direct link between glutathione biosynthesis and stress defense gene expression in Arabidopsis. The Plant Cell 16, 2448-2462.

Barbehenn RV, Jones CP, Yip L, Tran L, Constabel CP. 2007. Limited impact of elevated levels of polyphenol oxidase on treefeeding caterpillars: assessing individual plant defenses with transgenic poplar. Oecologia 154, 129-140.

Beckers GJM, Spoel SH. 2006. Fine-tuning plant defence signalling: salicylate versus jasmonate. Plant Biology 8, 1-10.

Bede JC, McNeil JN, Tobe SS. 2007. The role of neuropeptides in caterpillar nutritional ecology. Peptides 28, 185-196.

Bede JC, Musser RO, Felton GW, Korth KL. 2006. Caterpillar herbivory and salivary enzymes decrease transcript levels of Medicago truncatula genes encoding early enzymes in terpenoid biosynthesis. Plant Molecular Biology 60, 519-531.

Bell E, Creelman RA, Mullet JE. 1995. A chloroplast lipoxygenase is required for wound-induced jasmonic acid accumulation in Arabidopsis. Proceedings of the National Academy of Sciences, USA 92, 8675-8679.

Bell E, Mullet JE. 1993. Characterization of an Arabidopsis lipoxygenase gene responsive to methyl jasmonate and wounding. Plant Physiology 103, 1133-1137.

Bergmeyer HU. 1974. Methods of enzymatic analysis. Vol. I. Weinheim: Verlag Chemie.
Blanco F, Garretón V, Frey N, Dominguez C, Pérez-Acle T, Van der Straeten D, Jordana X, Holuigue L. 2005. Identification of NPR1-dependent and independent genes early induced by salicylic acid treatment in Arabidopsis. Plant Molecular Biology 59, 927-944.

Bodenhausen N, Reymond P. 2007. Signaling pathways controlling induced resistance to insect herbivores in Arabidopsis. Molecular Plant-Microbe Interactions 20, 1406-1420.

Bostock RM. 2005. Signal crosstalk and induced resistance: straddling the line between cost and benefit. Annual Review of Phytopathology 43, 545-580.

Boyes DC, Zayed AM, Ascenzi R, McCaskill AJ, Hoffman NE, Davis KR, Görlach J. 2001. Growth stage-based phenotypic analysis of Arabidopsis: a model for high throughput functional genomics in plants. The Plant Cell 13, 1499-1510.

Bradford MM. 1976. A rapid and sensitive method for the quantification of microgram quantities of proteins utilizing the principle of protein-dye binding. Analytical Biochemistry 72, 248-256.

Bruce TJA, Pickett JA. 2007. Plant defense signalling induced by biotic attacks. Current Opinion in Plant Biology 10, 387-392.

Brunner AM, Yakovlev IA, Strauss SH. 2004. Validating internal controls for quantitative plant gene expression studies. BMC Plant Biology 4, 14.

Cai X, Davis EJ, Ballif J, Liang M, Bushman E, Haroldsen V, Torabinejad J, Wu Y. 2006. Mutant identification and characterization of the laccase gene family in Arabidopsis. Journal of Experimental Botany 57, 2563-2569.

Chen H, Wilkerson CG, Kuchar JA, Phinney BS, Howe GA. 2005. Jasmonate-inducible plant enzymes degrade essential amino acids in the herbivore midgut. Proceedings of the National Academy of Sciences, USA 102, 19237-19242.

Chen Z, Silva H, Klessig DF. 1993. Active oxygen species in the induction of plant systemic acquired resistance by salicylic acid. Science 262, 1883-1886.

Chini A, Fonseca S, Fernández G, et al. 2007. The JAZ family of repressors is the missing link in jasmonate signalling. Nature $\mathbf{4 4 8}$, 666-671.

Cipollini DF, Enright S, Traw MB, Bergelson J. 2004. Salicylic acid inhibits jasmonic acid-induced resistance of Arabidopsis thaliana to Spodoptera exigua. Molecular Ecology 13, 1643-1653.

Clauss MJ, Mitchell-Olds T. 2004. Functional divergence in tandemly duplicated Arabidopsis thaliana trypsin inhibitor genes. Genetics 166, 1419-1436.

Creelman RA, Mullet JE. 1997. Biosynthesis and action of jasmonates in plants. Annual Review of Plant Physiology and Plant Molecular Biology 48, 355-381.

Day B, Dahlbeck D, Staskawicz BJ. 2006. NDR1 interaction with RIN4 mediates the differential activation of multiple disease resistance pathways in Arabidopsis. The Plant Cell 18, 2782-2791.

De Vos M, Van Oosten VR, Van Poecke RMP, et al. 2006. Signal signature and transcriptome changes of Arabidopsis during pathogen and insect attack. Molecular Plant-Microbe Interactions 18, 923-937.

Delessert C, Wilson IW, Van Der Straeten D, Dennis ES, Dolferus R. 2004. Spatial and temporal analysis of the local response to wounding in Arabidopsis leaves. Plant Molecular Biology 55, 165-181.

Després C, Chubak C, Rochon A, Clark R, Bethune T, Desveaux D, Fobert PR. 2003. The Arabidopsis NPR1 disease resistance protein is a novel cofactor that confers redox regulation of DNA binding activity to the basic domain/leucine zipper transcription factor TGA1. The Plant Cell 15, 2181-2191.

Devoto A, Nieto-Rostro M, Xie D, Ellis C, Harmston R, Patrick E, Davis J, Sherratt L, Coleman M, Turner JG. 2002. COI1 links jasmonate signalling and fertility to the SCF ubiquitinligase complex in Arabidopsis. The Plant Journal 32, 457-466. 
Devoto A, Turner JG. 2003. Regulation of jasmonate-mediated plant responses in Arabidopsis. Annals of Botany 92, 329-337.

Devoto A, Turner JG. 2005. Jasmonate-regulated Arabidopsis stress signalling network. Physiologia Plantarum 123, 161-172.

Dombrecht B, Xue G-P, Sprague SJ, et al. 2007. MYC2 differentially modulates diverse jasmonate-dependent functions in Arabidopsis. The Plant Cell 19, 2225-2245.

Dong X. 2004. NPR1, all things considered. Current Opinion in Plant Biology 7, 547-552.

Dow JAT. 1992. pH gradients in lepidopteran midgut. Journal of Experimental Biology 172, 355-375.

Duffey SS, Stout MJ. 1996. Antinutritive and toxic components of plant defense against insects. Archives of Insect Biochemistry and Physiology 32, 3-37.

Dufresne PJ, Thivierge K, Ide C, Ubalijoro E, Fortin MG. 2008. Class II poly(A)-binding proteins are essential for viability in Arabidopsis: role in growth, development and osmotic stress response. Plant Physiology and Biochemistry (in press).

Durrant WE, Dong X. 2004. Systemic acquired resistance. Annual Review of Phytopathology 42, 185-209.

Espín JC, Morales M, García-Ruiz PA, Tudela J, GarcíaCánovas F. 1997. Improvement of a continuous spectrophotometric method for determining the monophenolase and diphenolase activities of mushroom polyphenol oxidase. Journal of Agricultural and Food Chemistry 45, 1084-1090.

Fan W, Dong X. 2002. In vivo interaction between NPR1 and transcription factor TGA2 leads to salicyclic acid-mediated gene activation in Arabidopsis. The Plant Cell 14, 1377-1389.

Farmer EE, Alméras E, Krishnamurthy V. 2003. Jasmonates and related oxylipins in plant responses to pathogenesis and herbivory. Current Opinion in Plant Biology 6, 372-378.

Felton GW. 1996. Nutritive quality of plant proteins: sources of variation and insect herbivore responses. Archives of Insect Biochemistry and Physiology 32, 107-130.

Felton GW. 2005. Indigestion is a plant's best defense. Proceedings of the National Academy of Sciences, USA 102, 1877118772 .

Fobert PR, Després C. 2005. Redox control of systemic acquired resistance. Current Opinion in Plant Biology 8, 378-382.

Foyer CH, Noctor G. 2005. Redox homeostasis and antioxidant signaling: a metabolic interface between stress perception and physiological responses. The Plant Cell 17, 1866-1875.

Fujita M, Fujita Y, Noutoshi Y, Takahashi F, Narusaka Y, Yamaguchi-Shinozaki K, Shinozaki K. 2006. Crosstalk between abiotic and biotic stress responses: a current view from the points of convergence in the stress signaling networks. Current Opinion in Plant Biology 9, 436-442.

Galka PWS, Ambrose SJ, Ross ARS, Abrams SR. 2005. Syntheses of deuterated jasmonates for mass spectrometry and metabolism studies. Journal of Labelled Compounds and Radiopharmaceuticals 48, 797-809.

Garcia VA, das Graças Machado Freire M, Camillo Novello J, Marangoni S, Rodrigues Macedo ML. 2004. Trypsin inhibitor from Poecilanthe parviflora seeds: purification, characterization, and activity against pest proteases. Protein Journal 12, 343-350.

Glazebrook J, Rogers EE, Ausubel FM. 1996. Isolation of Arabidopsis mutants with enhanced disease susceptibility by direct screening. Genetics 143, 973-982.

Gupta R, Luan S. 2003. Redox control of protein tyrosine phosphatases and mitogen-activated protein kinases in plants. Plant Physiology 132, 1149-1152.

Halitschke R, Baldwin IT. 2005. Jasmonates and related compounds in plant-insect interactions. Journal of Plant Growth and Regulation 23, 238-245.
Han S, Kim D. 2006. AtRTPrimer: database for Arabidopsis genome wide homogeneous and specific RT-PCR primer-pairs. BMC Bioinformatics 7, 179.

Heintz T, Bergey DR, Ryan CA. 1997. A gene encoding a chloroplast-targeted lipoxygenase in tomato leaves is transiently induced by wounding, systemin, and methyl jasmonate. Plant Physiology 114, 1085-1093.

Howe GA. 2004. Jasmonates as signals in the wound response. Journal of Plant Growth Regulation 23, 223-237.

Huang X, Stettmaier K, Michel C, Hutzler P, Mueller MJ, Durner J. 2004. Nitric oxide is induced by wounding and influences jasmonic acid signaling in Arabidopsis thaliana. Planta 218, 938-946.

Jirage D, Zhou N, Cooper B, Clarke JD, Dong X, Glazebrook J. 2001. Constitutive salicylic acid-dependent signaling in $\mathrm{cprl}$ and cpr6 mutants requires PAD4. The Plant Journal 26, 395-407.

Kahl J, Simens DH, Aerts RJ, Gäbler R, Kühnemann F, Preston CA, Baldwin IT. 2000. Herbivore-induced ethylene suppresses a direct defense but not a putative indirect defense against an adapted herbivore. Planta 210, 336-342.

Kessler A, Baldwin IT. 2001. Defensive function of herbivoreinduced plant volatile emissions in nature. Science 291, 21412144.

Kessler A, Baldwin IT. 2002. Plant responses to insect herbivory: the emerging molecular analysis. Annual Review of Plant Biology 53, 299-328.

Kessler A, Halitschke R. 2007. Specificity and complexity: the impact of herbivore-induced plant responses on arthropod community structure. Current Opinion in Plant Biology 10, 409-414.

Kinkema M, Fan W, Dong X. 2000. Nuclear localization of NPR1 is required for activation of $P R$ gene expression. The Plant Cell 12, 2339-2350.

Koiwa H, Bressan RA, Hasegawa PM. 1997. Regulation of protease inhibitors and plant defense. Trends in Plant Science 2, 379-384.

Lara P, Ortega F, Gonzalez-Hidalgo E, Castañera P, Carbonera P, Diaz I. 2000. Adaptation of Spodoptera exigua (Lepidoptera: Noctuidae) to barley trypsin inhibitor BTI-CMe expressed in transgenic tobacco. Transgenic Research 9, 169-178.

León J, Lawton MA, Raskin I. 1995. Hydrogen peroxide stimulates salicylic acid biosynthesis in tobacco. Plant Physiology 108, 1673-1678.

Léon J, Rojo E, Sánchez-Serrano JJ. 2001. Wound signaling in plants. Journal of Experimental Botany 51, 1-9.

Li J, Brader G, Palva ET. 2004. The WRKY70 transcription factor: a node of convergence for jasmonate-mediated and salicylate-mediated signals in plant defense. The Plant Cell 16, 319-331.

Lorenzo O, Chico JM, Sánchez-Serrano JJ, Solano R. 2004. JASMONATE-INSENSITIVE1 encodes a MYC transcription factor essential to discriminate between different jasmonateregulated defense responses in Arabidopsis. The Plant Cell 16, $1938-1950$.

Lorenzo O, Solano R. 2005. Molecular players regulating the jasmonate signalling network. Current Opinion in Plant Biology 8, 532-540.

Lou Y, Baldwin IT. 2006. Silencing of a germin-like gene in Nicotiana attenuata improves performance of native herbivores. Plant Physiology 140, 1126-1136.

Mattson WJ Jr. 1980. Herbivory in relation to plant nitrogen content. Annual Review of Ecology and Systematics 11, 119-161.

Mayer AM. 2006. Polyphenol oxidases in plants and fungi: going places? A review. Phytochemistry 67, 2318-2331. 
McCraig BC, Meagher RB, Dean JFD. 2005. Gene structure and molecular analysis of the laccase-like multicopper oxidase (LMCO) gene family in Arabidopsis thaliana. Planta 221, 619-636.

Miao Y, Zentgraf U. 2007. The antagonistic function of Arabidopsis WRKY53 and ESR/ESP in leaf senescence is modulated by the jasmonic acid and salicylic acid equilibrium. The Plant Cell 19, 819-830.

Mou Z, Fan W, Dong X. 2003. Inducers of plant systemic acquired resistance regulate NPR1 function through redox changes. Cell 113, 935-944.

Mueller MJ. 1997. Enzymes involved in jasmonic acid biosynthesis. Physiologia Plantarum 100, 653-663.

Musser RO, Cipollini DF, Hum-Musser SM, Williams SA, Brown JK, Felton GW. 2005. Evidence that the caterpillar salivary enzyme glucose oxidase provides herbivore offense in Solanaceous plants. Archives of Insect Biochemistry and Physiology 58, 128-137.

Musser RO, Hum-Musser SM, Eichenseer H, Peiffer M, Ervin G, Murphy JB, Felton GW. 2002. Caterpillar saliva beats plant defences: a new weapon emerges in the evolutionary arms race between plants and herbivores. Nature 416, 599-600.

Ndamukong I, Abdallat AA, Thurow C, Fode B, Zander M, Weigel R, Gatz C. 2007. SA-inducible Arabidopsis glutaredoxin interacts with TGA factors and suppresses JA-responsive PDF1.2 transcription. The Plant Journal 50, 128-139.

Orozco-Cárdenas M, Ryan CA. 2002. Nitric oxide negatively modulates wound signaling in tomato plants. Plant Physiology 130, 487-493.

Penninckx IAMA, Thomma BPHJ, Buchala A, Metraux JP, Broekaert WF. 1998. Concomitant activation of jasmonate and ethylene response pathways is required for induction of a plant defensin gene in Arabidopsis. The Plant Cell 10, 2103-2113.

Pieterse CM, van Loon L. 2004. NPR1: the spider in the web of induced resistance signaling pathways. Current Opinion in Plant Biology 7, 456-464.

Pourcel L, Routaboul J-M, Cheynier V, Lepiniec L, Debeaujon I. 2007. Flavonoid oxidation in plants: from biochemical properties to physiological functions. Trends in Plant Science 12, 29-36.

Rayapuram C, Baldwin IT. 2007. Increased SA in NPRI-silenced plants antagonizes JA and JA-dependent direct and indirect defenses in herbivore-attacked Nicotiana attenuata in nature. The Plant Journal 52, 700-715.

Reymond P, Bodenhausen N, Van Poecke RMP, Krishnamurthy V, Dicke M, Farmer EE. 2004. A conserved transcript pattern in response to a specialist and a generalist herbivore. The Plant Cell 16, 3132-3147.

Rojo E, Solano R, Sánchez-Serrano JJ. 2003. Interactions between signaling compounds involved in plant defense. Journal of Plant Growth and Regulation 22, 82-98.

Ross ARS, Ambrose SJ, Cutler AJ, Feurtado JA, Kermode AR, Nelson KM, Zhou R, Abrams SR. 2004. Determination of endogenous and supplied deuterated abscisic acid in plant tissues by HPLC-ESI MS/MS with MRM. Analytical Biochemistry 329, 324-333.

Sasaki Y, Asamizu E, Shibata D, et al. 2001. Monitoring of methyl jasmonate responsive genes in arabidopsis by cDNA macroarray: self-activation of jasmonic acid biosynthesis and crosstalk with other phytohormone signaling pathways. DNA Research 8, 153-161.

Schultz JC, Lechowicz MJ. 1986. Host plant, larval age, and feeding behavior influence midgut $\mathrm{pH}$ in the gypsy moth (Lymantria dispar). Oecologia 71, 133-137.

Sellés-Marchant S, Casado-Vela J, Bru-Martínez R. 2007. Effect of detergents, trypsin and unsaturated fatty acids on latent loquat fruit polyphenol oxidase: basis for the enzyme's activity regulation. Archives of Biochemistry and Biophysics 464, 295305.

Senda K, Ogawa K. 2004. Induction of PR-1 accumulation accompanied by runaway cell death in the $l s d l$ mutant of Arabidopsis is dependent on glutathione levels but independent of the redox state of glutathione. Plant and Cell Physiology 45, $1578-1585$.

Shapiro AD, Zhang C. 2001. The role of NDRI in avirulence gene-directed sigaling and control of programmed cell death in Arabidopsis. Plant Physiology 127, 1089-1101.

Simon ML, László K, Kotormán M, Szajáni B. 2001. A comparative study of the conformational stabilities of trypsin and a-chymotrypsin. Acta Biologica Szegediensis 45, 43-49.

Spoel SH, Johnson JS, Dong X. 2007. Regulation of tradeoffs between plant defenses against pathogens with different lifestyles. Proceedings of the National Academy of Sciences, USA 104, 18842-18847.

Spoel SH, Koornneef A, Claessens SMC, Korzelius JP, Van Pelt JA, Dong X, Pieterse CM. 2003. NPR1 modulates crosstalk between salicylate- and jasmonate-dependent defense pathways through a novel function in the cytosol. The Plant Cell 15, 760-770.

Stotz HU, Pittendrigh BR, Kroymann J, Weniger K, Fritsche J, Bauke A, Mitchell-Olds T. 2000. Induced plant defense responses against chewing insects. Ethylene signaling reduces resistance of Arabidopsis against Egyptian cotton worm but not diamondback moth. Plant Physiology 124, 1007-1017.

Thines B, Katsir L, Melotto M, Niu Y, Mandaokar A, Liu G, Nomura K, He YS, Howe GA, Browse J. 2007. JAZ repressor proteins are targets of the $\mathrm{SCF}^{\mathrm{CoI} 1}$ complex during jasmonate signaling. Nature 448, 661-665.

Torres MA, Jones JDG, Dangl JL. 2006. Reactive oxygen species signaling in response to pathogens. Plant Physiology 141, 373-378.

Turlings TCJ, Alborn HT, Loughrin JH, Tumlinson JH. 2000. Volicitin, an elicitor of maize volatiles in oral secretion of Spodoptera exigua: isolation and bioactivity. Journal of Chemical Ecology 26, 189-202.

Vick BA, Zimmerman DC. 1976. Lipoxygenase and hydroperoxide lyase in germinating watermelon seedlings. Plant Physiology 57, 780-788.

Voelckel C, Baldwin IT. 2004. Generalist and specialist lepidopteran larvae elicit different transcriptional responses in Nicotiana attenuata, which correlate with larval FAC profiles. Ecological Letters 7, 770-775.

Vogel H, Kroymann J, Mitchell-Olds T. 2007. Different transcript patterns in response to specialist and generalist herbivores in the wild Arabidopsis relative Boechera divaricarpa. PLOS ONE 2, e1081.

von Dahl CC, Baldwin IT. 2007. Deciphering the role of ethylene in plant-herbivore interactions. Journal of Plant Growth and Regulation 26, 201-209.

Walling LL. 2000. The myriad of plant responses to herbivore. Journal of Plant Growth and Regulation 19, 195-216.

Wang D, Amornsiripanitch N, Dong X. 2006. A genomic approach to identify regulatory nodes in the transcriptional network of systemic acquired resistance in plants. PLOS Pathogens 2, 1042-1050.

Wang J, Constabel CP. 2004. Polyphenol oxidase overexpression in transgenic Populus enhances resistance to herbivory by forest tent caterpillar (Melacosoma disstria). Planta 220, 87-96.

Wasternack C. 2007. Jasmonates: an update on biosynthesis, signal transduction and action in plant stress response, growth and development. Annals of Botany 100, 681-697. 
Wasternack C, Stenzel I, Hause B, Hause G, Feussner I, Miersch O. 2006. The wound response in tomato. Role of jasmonic acid. Journal of Plant Physiology 163, 297-306.

Winz R, Baldwin IT. 2001. Molecular interactions between the specialist herbivore Manduca sexta (Lepidoptera, Sphingidae) and its natural host Nicotiana attenuata. IV. Insect-induced ethylene reduces jasmonate-induced nicotine accumulation by regulating putrescine $\mathrm{N}$-methyltransferase transcripts. Plant Physiology 125, 2189-2202.

Wu J, Hattenhausen C, Baldwin IT. 2006. Evolution of proteinase inhibitor defenses in North American allopolyploid species of Nicotiana. Planta 224, 750-760.

Xu L, Liu F, Lechner E, Genschik P, Crosby WL, Ma H, Peng W, Huang D, Xie D. 2002. The $\mathrm{SCF}^{\mathrm{CoI1}}$ ubiquitin-ligase complexes are required for jasmonate response in Arabidopsis. The Plant Cell 14, 1919-1935.

Yoruk R, Marshall MR. 2003. Physicochemical properties and function of plant polyphenol oxidase: a review. Journal of Food Biochemistry 27, 361-422.

Zavala JA, Patankar AG, Gase K, Hui D, Baldwin IT. 2004. Manipulation of endogenous trypsin proteinase inhibitor pro- duction in Nicotiana attenuata demonstrates their function as antiherbivore defenses. Plant Physiology 134, 1181-1190.

Zhang C, Gutsche AT, Shapiro AD. 2004. Feedback control of the Arabidopsis hypersensitive response. Molecular Plant-Microbe Interactions $\mathbf{1 7}, 357-365$.

Zhang C, Shapiro AD. 2002. Two pathways act in an additive rather than obligatorily synergistic fashion to induce systemic acquired resistance and $P R$ gene expression. BMC Plant Biology $2,9$.

Zheng S-J, van Dijk JP, Bruinsma M, Dicke M. 2007. Sensitivity and speed of induced defense of cabbage (Brassica oleracea L.): dynamics of BoLOX expression patterns during insect and pathogen attack. Molecular Plant-Microbe Interactions 20, 1332-1345.

Zhu-Salzman K, Bi J-L, Liu T-X. 2005. Molecular strategies of plant defense and insect counter-defense. Insect Science 21, 3-15. Ziegler J, Keinaenen M, Baldwin IT. 2001. Herbivore-induced allene oxide synthase transcripts and jasmonic acid in Nicotiana attenuata. Phytochemistry 58, 729-738. 